natural course before consideration is given as to whether treatment is justified.

Senior Registrar in Old Age Psychiatry,

JOHN T O'BRIEN

Fulbourn Hospital,

Cambridge CB1 5EF

Professor of Old Age Psychiatry,

RAYMOND LEVY

Institute of Psychiatry,

London SE5 8AF

1 Brody $\mathrm{H}$. The deposition of aging pigment in the human cerebral cortex. $f$ Geronto 1960;15:258-61.

2 Tomlinson BE, Kitchener D. Granulovacuolar degeneration of the hippocampal pyramidal cells. f Pathol 1972;106:165-85.

3 Scheibel ME, Scheibel AB. Structural changes in the ageing brain. In: Brody H, Harman D, Ordy JM, eds. Aging. Vol 1. New York: Raven Press, 1975:11-37.

4 Tomlinson BE, Henderson G. Some quantitative cerebral findings in normal and demented old people. In: Terry RD, Gershon S, eds. Neurobiology of ageing. New York: Raven Press, 1976:183-204.

5 Kral VA. Neuropsychiatric observations in an old people's home. F Gerontol 1958;13:169-76.
6 Kral VA. Senescent forgetfulness: benign and malignant. Can Med Assoc $\mathcal{J}$ 1962;86:257-60.

7 Reisberg B, Ferris SH, Shulman E, Steinberg G, Buttinger C, Sinaik O, et al. Longitudinal course of normal ageing and progressive dementia of the Alzheimer's type: a prospective study of 106 subjects over a 3.6 year mean interval. Prog Neuropsychopharmacol Biol Psychiatry 1986;10:571-8. Larrabee GJ, Levin HS, High WM. Senescent forgetfulness: a quantitative study. Developmental Neuropsychology 1986;2:373-85.

9 Kral VA. Benign senescent forgetfulness. In: Katzman R, Terry BD, Bick KL, eds. Alzheimer's disease: senile dementia and related disorders (Ageing vol 7). New York: Raven Press, 1978:47-51. 10 Brayne C, Calloway P. Normal ageing, impaired cognitive function, and senile dementia of the Alzheimer's type: a continuum? Lancet 1988;i:1265-7.

1 Bowen DM, White P, Spillane JA, Goodhart MJ, Curzon G, Iwangoff $P$, et al. Accelerated ageing or selective neuronal loss as an important cause of dementia? Lancet 1979;i:11-4.

2 Huppert FA, Kopelman MD. Rates of forgetting in normal ageing: a comparison with dementia. Neuropsychologia 1989;27:849-60.

13 Hyslop PHStG, Tanzi RE, Polinsky RJ, Haines JL, Nee L, Watkins PC, et al. The genetic defect causing familial Alzheimer's disease maps on chromosome 21. Science 1987;235:885-90.

14 Crook T, Bartus RT, Ferris SH, Whitehouse P, Cohen GD, Gershon S, et al. Age associated memory impairment: proposed diagnostic criteria and measures of clinical change--report of a National Institute of Mental Health work group. Developmental Neuropsychology 1986;2:261-76. 15 McEntee WJ, Crook TH. Age-associated memory impairment: a role for catecholamines. Neurology 1990;40:526-30.

16 Robins E, Guze SB. Establishment of diagnostic validity in psychiatric illness: its application to schizophrenia. Am $\mathcal{F}$ Psychiatry 1970;126:983-7.

17 Wyke A. Memory boosters blow up a storm. Daily Telegraph 1991 June 10:12(col 5-6)

18 Crook TH, Tinkleberg J, Yesavage J, Petrie W, Nunzi MG, Massari DC. Effects of phosphatidylserine in age-associated memory impairment. Neurology 1991;41:644-9.

\title{
Democracy at work
}

\section{That GPs fill in next week's survey is important not only for them}

Next week sees one of the BMA's biggest exercises yet in practical democracy. All Britain's 35000 general practitioners will receive a 19 page questionnaire survey asking them how they see the future of general practice. The questionnaire comes from the General Medical Services Committee of the BMA and is part of the consultation surrounding Building Your Own Future-its attempt to provide a blueprint for general practice in the 1990s. ${ }^{1}$ The committee hopes for an excellent response rate. If its hopes are fulfilled the exercise has lessons beyond general practice.

All big organisations risk growing out of touch with their members, but few are tested quite so starkly as was the General Medical Services Committee when the government imposed a new contract on general practitioners in 1990. Stuck between an intransigent government and a profession unwilling to compromise, the general practitioners' negotiators found themselves ignored by government and untrusted by the members, clutching a briefcase of obsolete policies. Their response has been a determined attempt to raise fundamental questions - to think the unthinkable - and to find out what general practitioners want from general practice in the new NHS. Starting from scratch in this way means that the profession can set its own agenda and not simply be forced to react to that of a more radical government.

Next week's survey is only one part of a carefully planned consultation. The process started when Building Your Own Future was sent to all general practitioners last June. This raised an exhaustive set of questions about general practiceits organisation, financing, quality, and content. From the responses, which have come from local medical committees, trainees' groups, outside organisations, a $B M \mathcal{F}$ series, ${ }^{2}$ and individual practices and doctors, four main subjects have so far emerged. Your Choices for the Future, sent out in October, discusses these four issues in detail: means of payment, the 24 hour commitment, the content of general practice, and maintaining standards. ${ }^{3}$ Now comes the survey, covering these issues and others and designed to avoid throwing up simplistic answers. Once the answers have been analysed the findings will be sent to all general practitioners and discussed at a special conference in the summer. Each local medical committee will also receive a breakdown of the responses in its own area.
Consultation-with members, staff, customers, clients, patients, the public - is part of the spirit of the times. The BMA's document Leading for Health ${ }^{4}$ does for the entire health service what Building Your Own Future does for general practice, and the BMA too is looking for an informed debate to help it devise coherent future policies. In the NHS itself providers are being urged to find out what their patients think and purchasers what their publics need. Debates about what choices to make in health are difficult enough to conduct among professionals. ${ }^{56}$ To engage the public as well will demand a sophistication of the process of debate not seen before in the NHS - or in any other sphere of public life. The GMSC's technique of raising the questions, listening to the feedback, providing balanced information to inform the debate, going out again with a more detailed set of questions (to everyone, not just those who responded first time round) is a good model for how such debates could be conducted. If general practitioners do not respond well to next week's survey their negotiators will not be the only people to be disappointed.

Deputy editor, $B M \mathcal{F}$

JANE SMITH

\footnotetext{
1 General Medical Services Committee. Building your own future: an agenda for general practice. London: GMSC, 1991

2 The future of general practice. London: $B M \mathcal{Y}$ (in press).

3 General Medical Services Committee. Your choices for the future. London: GMSC, 1991.

4 British Medical Association. Leading for health: a BMA agenda for health. London: BMA, 1991.

5 Cochrane M, Ham C, Heginbotham C, Smith R. Rationing: at the cutting edge. BMf 1991:303:1039-42.

6 Smith R. Rationing: the search for sunlight. BMf 1991:303:1561-2.
}

\section{Corrections}

\section{Artificial blood}

An author's error occurred in this editorial by S J Urbaniak (30 November, p 1348). The editorial stated that Fluosol DA20 may be used in Britain only on a named patient basis; in fact, Fluosol is fully licensed for use in the United Kingdom

\section{How well do we manage families with genetic problems?}

We regret that the names of two members of the steering committee of the national confidential inquiry into counselling for genetic disorders were missed out of Professor Rodney Harris's editorial (7 December, p 1412). They were Professor Charles Rodeck and Dr Bernadette Modell. 